\section{Private/public rat genome consortium formed}

Celera Genomics (Rockville, MD), the Baylor College of Medicine (Baylor, TX), and Genome Therapeutics (Waltham, MA) plan to produce a four-fold draft sequence of the $3 \mathrm{~Gb}$ rat genome within the next two years. The collaborative effort will involve whole genome shotgun sequencing using BAC clones chosen from map data provided by the Institute for Genomic Research (TIGR; Rockville, MD) and the British Columbia Cancer Research Centre (BCCRC; Vancouver, Canada). Data will be released weekly into public databases at the National Center for Biotechnology Information (http://www.ncbi.nlm.nih.gov/). Celera and Baylor have received $\$ 58$ million from The National Heart, Lung, and Blood Institute (NHLBI; Bethesda, MD) and the National Human Genome Research Institute (NHGRI; Bethesda, MD), which have also given grants to Genome Therapeutics, TIGR, and the BCCRC.

$A B$

\section{I3C provides bioinformatics platform}

On February 16, Sun Microsystems (Palo Alto, $\mathrm{CA}$ ) announced the initiation of a public-private Informatics Interoperable Infrastructure Consortium (I3C) to develop an open web-

\section{India's biotech budget hiked}

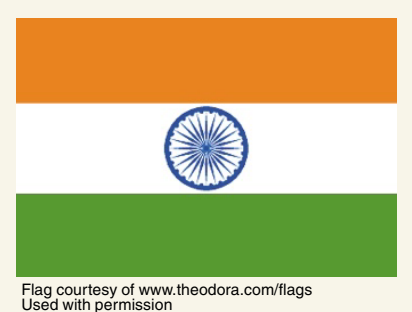

On 28 February, the Indian government announced a biotech R\&D budget increase of Rs.360 million ( $\$ 8$ million) to Rs.1.86 billion for public research institutes and universities for the coming financial year. There will also be a hefty tax exemption for biotech companies whereby Rs.150 can be deducted from taxable income for every Rs.100 spent on R\&D. "This is really going to lead to an explosive growth of $\mathrm{R} \& \mathrm{D}$ in pharmaceutical and biotech companies that have begun investing in $\mathrm{R} \& \mathrm{D}$ in anticipation of product patents," says Ragunath Mashelkar, secretary of the Department of Scientific and Industrial Research. India will begin recognizing product patents from 1 January 2005, in accordance with the World Trade Organization (Nat. Biotechnol. 17, 8, 1999). Mashelkar says the tax exemptions are expected to boost various drug development efforts involving India's 2000-year-old herbal remedies. The budget hike will also allow India's Department of Biotechnology to establish a National Bioresource Board "to develop, conserve, and utilize biological resources of the country by using biotechnology."

KJ based platform for sharing, integrating, and interoperating data for a broad variety of biotech-oriented fields, including genomics, proteomics, and bioinformatics. The idea was hatched at Sun's Life Science Advisory Council summit in December, when council representatives, including Oxford Glycosciences (Abingdon, UK) and Monsanto (St. Louis, $\mathrm{MO}$ ), complained that "a significant portion of [their] IT resources and capital has been used on integration," says Sia Zadeh, group manager of Sun's life sciences division. The Biotechnology Industry Organization (Washington, DC) and the National Cancer
Institute (Bethesda, MD) will participate in I3C, as will such IT companies as LabBook (Columbus, $\mathrm{OH}$ ) and Time Logic (Incline Village, NV). The new platform will be based on the eXtensive Markup Language (XML) and Java, and should save time by allowing researchers to consolidate and edit multiple databases over the internet. As LabBook's Adel Mikhail says, the platform development is an effort to "at least keep up with Moore's law," which states that computing power doubles about every 18 months-much slower than genetic data's trend of octupling in size in the same period.

\begin{tabular}{|c|c|c|c|}
\hline \multicolumn{4}{|c|}{ Research collaborations } \\
\hline Company 1 & Company 2 & \multicolumn{2}{|c|}{ \$ (million) } \\
\hline $\begin{array}{l}\text { Abbott Laboratories } \\
\text { (Abbott Park, IL) }\end{array}$ & $\begin{array}{l}\text { Millennium } \\
\text { Pharmaceuticals } \\
\text { (Cambridge, MA) }\end{array}$ & 250 & $\begin{array}{l}\text { An exclusive agreement to develop and commercialize drugs and molecular diagnostics } \\
\text { for the treatment and management of diabetes and obesity. Millennium's genomics-based } \\
\text { target discovery platform will be combined with Abbott's drug development, manufacturing, } \\
\text { commercialization, and diagnostic expertise. Abbott will purchase } \$ 50 \text { million of } \\
\text { Millennium's stock initially, and } \$ 200 \text { million more over the next two years. }\end{array}$ \\
\hline $\begin{array}{l}\text { Amrad } \\
\text { Pharmaceuticals } \\
\text { (Richmond, Australia) }\end{array}$ & $\begin{array}{l}\text { GlaxoSmithKline } \\
\text { (GSK; Brentford, } \\
\text { UK) }\end{array}$ & 25 & $\begin{array}{l}\text { A two-year exclusive collaboration to discover novel therapies for the treatment of cancer and } \\
\text { infectious diseases. Amrad's Suppressors of Cytokine Signaling platform will be used to design } \\
\text { cell-specific drugs. GSK will fund Amrad's R\&D, as well as pay up to } \$ 25 \text { million in milestone } \\
\text { payments and royalties if products are discovered. }\end{array}$ \\
\hline $\begin{array}{l}\text { Immusol } \\
\text { (San Diego, CA) }\end{array}$ & $\begin{array}{l}\text { Medarex } \\
\text { (Princeton, NJ) }\end{array}$ & 5 & $\begin{array}{l}\text { A joint effort to produce fully human therapeutic antibodies to an array of previously } \\
\text { untargeted diseases. Immusol will sift through its library of over } 10 \text { million different ribozyme } \\
\text { genes to discover and validate potentially therapeutic targets, and then Medarex will } \\
\text { develop the antibodies. Medarex will pay Immusol } \$ 5 \text { million, and both companies will share } \\
\text { responsibilities from preclinical development to marketing efforts. }\end{array}$ \\
\hline $\begin{array}{l}\text { Aurelium BioPharma } \\
\text { (ABP; Laval, } \\
\text { Canada) }\end{array}$ & $\begin{array}{l}\text { KS Biomedix } \\
\text { (KSB; London) }\end{array}$ & * & $\begin{array}{l}\text { A deal to design antibodies to either reverse, modify, or target and kill multiple-drug-resistant } \\
\text { (MDR) tumor cells in both blood cancers and solid-tumor cancers. ABP will provide novel } \\
\text { protein targets that are expressed in MDR cancer cells for KSB's super-high-affinity } \\
\text { monoclonal antibody technology. Multiple-drug resistance is the major factor for the limited } \\
\text { success of chemotherapies. }\end{array}$ \\
\hline $\begin{array}{l}\text { genOway } \\
\text { (Lyons, France) }\end{array}$ & $\begin{array}{l}\text { Syn X Pharma } \\
\text { (Mississauga, } \\
\text { ON, Canada) }\end{array}$ & * & $\begin{array}{l}\text { A joint venture to develop drug targets for use against cardiovascular and central nervous disorders. } \\
\text { genOway will develop transgenic animal models to test Syn X's novel protein library, } \\
\text { and the two companies will share intellectual property as well as revenues from products and services. }\end{array}$ \\
\hline
\end{tabular}

*Financial details not disclosed 